\title{
Using Collaborative Learning Strategies to Improve Creativity in EFL Writing: Attitudes and Actual Use
}

Luqman M. Rababah*

\begin{abstract}
This qualitative study aims at exploring the collaborative learning strategies adopted by EFL teachers. The study also investigates the actual use of these strategies among the participants. Ten EFL teachers have been chosen based on the convenience sampling. To answer the research questions, the present study has made use of two instruments, namely interviews and observations. The interview results revealed that the participating teachers expressed their opinions on how they used collaborative learning strategy for promoting their students' creativity in EFL writing. Classroom observations revealed that all the teachers who claimed to employ this strategy used a combined set of collaborative teaching activities. Additional research should be conducted and results should be interpreted and spread in the field for effective professional development.
\end{abstract}

Keywords: collaborative learning, creative writing, secondary school, EFL writing

\section{Introduction}

Learning is considered to be more effective and productive if learning is focused on a goal, regulated by the learner, and occurs in interaction and collaboration with others. Learning is also effective if it has been based on constructive knowledge processes and the acquisition of skills (Buchberger, 2001). Considering the increasing proliferating acknowledgement of the interactive and collaborative learning benefits, constructivism has been seen to impact communicative language teaching by its stress on learnercentred teaching methods and the significance of language use in communication and making meanings (Hymes, 1971).

Collaborative learning is described as a philosophy of working, building, and learning, changing and improving together and is a philosophy that is well-suited for the current globalized world (William, 2009). William (2009) said that writing is both a cognitive activity and a social activity that requires $L 2$ students to interact and discuss ideas in pairs or small groups. The importance of collaborative learning and the lack in this field pushes the research to conduct the current study. This study has two main research questions:

1. What are the attitudes of EFL teachers toward using collaborative learning strategies in writing?

2. What is the actual use of these strategies by EFL teachers?

\footnotetext{
* School of Arts and Languages, Jadara University, Jordan 


\section{Literature Review}

\section{Communicative Language Approach (CLT)}

One distinct CLT characteristic is its learner-centeredness (Rodgers, 2001) and, in this regard, individual learner differences take importance. Individuals vary on the basis of their attitudes, behaviour, skills, aptitudes, preferences, motivation, information processing abilities and developing meaning from information (Bygate, Swain, \& Skehan, 2013). In second language acquisition, individual differences are examined with regards to aptitude, motivation, learner strategies and styles (Dornyei \& Kubanyiova, 2014; Dornyei \& Skehan, 2008).

Communication competence is the ultimate goal of communicative language teaching because learners become able to use language effectively to make meaning as opposed to merely learning grammatical structures and phrases through rote. Rote is useful in learning, but the point behind communicative competence is to employ meaningful language in contextualized sociocultural activities. Such a premise has influenced education and educational reforms in many ways. First, the premise that language comprises grammatical structures or lexical items has shifted specifically via methods of communicative language teaching that concentrate on forming meanings in language.

In this regard, Hymes (1971) proposed that the notion of communicative competence includes the knowledge of when, what and how to say to whom. The introduction of communicative language teaching methods in education and language teaching has proliferated in the past decades by motivating learners to speak and use the language to understand and develop meaning. Second, learning has been considered lately to be a crucial goal for Europe to create a group of pro-active thinkers and self-regulated individuals to improve the capacity of human resource (Ekholm et al., 2007). Both the advent of globalization and the increasing use of the English Language are boosting English teaching for international business and have brought about an increased diversity of learners learning English. Consequently, innovative teaching and learning methods are being extending in an attempt to create inclusive educational experiences. As such, the experiential methods for communicative language teaching have been formed on the basis of constructivist principles, and educational innovations have started to influence reforms in the educational field. Effective learning environments are still new and, to date, effective learning environments have often utilized computer technology that have been developed with the knowledge that learning should go beyond the present norm. It has also been acknowledged that learning can occur in several ways, specifically with engaged and active learners (Gerjets, Scheiter, Opfermann, Hesse, \& Eysink, 2009).

Several distinct characteristics of the CLT approach can be derived from the literature, which are: authentic materials, pair and group work, creative and critical thinking, developing language awareness and differences in learners. Authentic materials are considered to be real-life materials in the language classroom including divergent texts, pictures, applications, videos, among other resources, which are not particularly developed towards a specific pedagogy (Rodgers, 2001).

The expansive integration of authentic materials in language classrooms is among the instructional practices advocated by the CLT. The premise behind using authentic material lies in the fact that they contain authentic language and its actual use. Through authentic real-life materials, students are exposed to the natural occurrence of the language, like real-life telephone situations. Students are linked to the requirements of the learning, and they become able to bridge the gap between classroom and real life (Brandl, 2007).

In pair and group work, the CLT procedures require that teachers shift from teacher-cantered classroom management skills towards more student-centred skills in which teachers must organize their classes in ways that facilitate student communication. 
Collective work in teams of students (pairs or groups) is facilitated to achieve a task and goals with the help of the target language. Student interaction is expected to occur among students and between students and among teachers (Brandl, 2007). Thus, student groups can promote cooperative and collaborative learning, which has been deemed to be an effective learning facilitator (Parrish, 2004).

In creative and critical thinking, CLT advocates stress strongly the contention that students learning English must be provided with chances to take part in high-level thinking and problem solving. According to these advocates, using inquiry and problem-based learning is suitable in promoting creative and critical thinking of students (Auerbach \& Wallerstein, 1987). In the field of language teaching, the work of Al-Nouh, Abdul-Kareem and Taqi (2014) suggests that CLT and task-based teaching are - the most extensively utilized methods as they stress on creativity via actual communication and ideas exchange in the context of group work activities (p. 8). Task-based teaching is a methodology that is widely used in language learning (Bygate et al., 2013; Willis \& Willis, 2008) and is believed to be an approach that enjoys the potential to make up for the inadequacies of CLT and can be considered as —a logical development of it (Rodgers, 2001, p. 223). Bygate et al. (2013) defined a task as —an activity, which requires learners to use language, with emphasis on meaning, to attain an objective (p. 11).

Building language awareness refers to teaching the actual use of language - in other words, teaching language in a context, in which teaching considers the appropriate use of the language in the social context. Two types of contextualized English Languages exist. The first is ESP or English for Special Purposes. In this type of contextualized English, English is specifically adapted for science, business or technology. The second is contextualized English, which refers to a dialect whereby the learner develops the language in a context and involves himself with a distinct group of speakers. Teachers of the English Language have a responsibility to create contexts wherein English Language learners are scaffolded with the help of an activity system the teaching and the learner create together (Rababah, 2018; Rababah \& Banikalef, 2019; Rababah \& Almwajeh, 2018). The designed activities should have purpose and should satisfy the needs of the learners in order to facilitate their understanding of the language and its cultural implications. This context type relays meaning and enjoyment, and learners are deserving of such an effective environment (Díaz-Rico, 2008).

Krashen (1982) considered language instruction from the communicative perspective in terms of offering comprehensible input of (and by assisting) students to enter various actual social discourse situations and discourse communities. Learners would actually face such circumstances and communities outside of their classrooms. To assist learners handle actual situations, foreign language and second-language teachers should employ task-based learning in which students take part in actual tasks and projects (Long \& Crookes, 1992). In carrying out such activities, the learners exchange and discuss meanings in order to develop their language in the particular language system. Their engagement in actual tasks and projects in a meaningful way could enhance learners' communicative skills in a second/foreign language.

In other words, a communicative language teacher is responsible for responding and addressing each learner's language requirements, and he/she can carry out this responsibility by developing informal one-to-one sessions with the students where in both the teacher and the student can rehash issues including a student's perceptions of his/her learning styles, his/her preferences and learning assets as well as aims. In the classroom, teaching material can be selected and a teaching style can be adopted that used that meets the requirements of learners (Rodgers, 2001). 


\section{Related Studies}

Because L2 writing is an invaluable process and product, requiring social exchange of meaning, a need exists to determine the importance of collaboration in L2 learning. Many studies have been conducted (Biria \& Jafari, 2013; Rojas-Drummond, Albarrán, \& Littleton, 2008; Rojas-Drummond, Mazón, Fernández, \& Wegerif, 2006)

Biria and Jafari (2013) examined the impact of practicing in pairs on the writing fluency of Iranian EFL learners. To this end, an OPT test was administered to 90 homogenous learners female EFL learners at an intermediate level. Afterwards, the participants were randomly divided into two groups comprising a control group of 30 students and an experimental group of 60 learners working in pairs. Each group produced a written text individually. The results showed the average number of words, T-units, and clauses in individual essays for the control group were more for the pairs. The essays written in the last session revealed a considerable improvement in the use of T-units and clauses produced by pairs. The findings also revealed that practicing in pairs improved the overall quality of the learners' writing productions. Hayes and Ge (2008) examined the impact of a collaborative learning environment on the writing performance and outcomes of fifth graders in the United States. The study comprised thirtyfour students who participated in a real-world writing project, taking on the roles of journalists and editors in creating a school newspaper. The groups included a computer supported collaborative group (CSCL) and a control group who participated in the writing tasks. A web-based software knowledge forum supported the CSCL GROUP, and the control group was supported by the use of paper and pencil. The students were then observed and interviewed for their feedback. The findings showed that the CSCL group displayed significant gains in writing skills and showed more motivation compared to their controlled group counterparts.

Rojas-Drummond et al. (2008) explored how primary school children learned to collaborate and collaborate to learn in creative writing projects using ICT. The analysis centred on examples of dialogues, texts and multimedia products of stories that groups of 4th grade (9- to 10 year-olds) children created. Overall, the work revealed the dynamic functioning of central sociocultural concepts in educational settings. These included: co-construction; intersexuality and inter-conceptuality among oracy, literacy and uses of ICT; collaborative creativity; development of dialogical and text production strategies and appropriation of diverse cultural artifacts for constructing knowledge. Rojas-Drummond et al. (2006) investigated using novel teaching methods like cooperative learning, teaching of critical thinking, and exploratory talk on students. The results indicated a significant increase in the students' creativity test gained by using those methods

\section{Methods and Procedures}

This study adopted the qualitative approach. Using the convenience sampling, this study has chosen ten EFL teachers from public schools in Irbid, Jordan. All the participants are from secondary stage. To answer the research questions, the teachers were requested to answer the interview questions and to be observed while teaching. The interviews and observations were audio recorded and transcribed verbatim. The researcher sets forth his goals while closely listening to the recordings, and they went through the answers of the participants three times, and transcribed the responses. 


\section{Results}

Research Question one: What are the attitudes of EFL teachers towards using collaborative learning strategies in writing?

The participating teachers in the study expressed their feelings on how they made use of the collaborative learning strategy for promoting their students' creativity in EFL writing. Some of their responses are discussed under this sub-title. Participating teacher TA claimed, -my focus is on collaborative learning where in students displaying different levels of performance work together in small groups to achieve a common goal (TA, Interview, April 1, 2018). Similarly, TC mirrored the above statement by saying, 一the students are accountable and responsible for their learning and for others. Hence, the success of one student could help in the success of others (TC, Interview, April 7, 2019). TF explained the manner in which he used this strategy. - The students are grouped into four (A, B, C and D). They sat in groups to discuss the writing task and to re-check their peer's work (TF, Interview, April 13, 2018).

Another teacher participant, TI, had a similar description. He stated that —students sit in a group in order to work together and to develop their EFL writing creativity as this development requires the students' interaction among each other to express their feelings and ideas (TI, Interview, April 25, 2018). Participating teachers were convinced that students might need collaborative learning to work together, progress together, learn together, change together and improve together. Encouraging students to keep on writing was the next step to assist the students in enhancing their writing abilities. Once the students began writing, the teachers employed two strategies to keep them writing, namely, collaborative learning and ICT integration.

Research Question two: What is the actual use of these strategies by EFL teachers?

Classroom observations revealed that all the teachers who claimed to employ this strategy used a combined set of collaborative teaching activities like working in groups (WG), working in pairs (WP), and whole-class teaching (WC). This occurrence of this strategy is shown in Table 3.2, according to the implementation of each teacher.

Table 1 Collaborative learning strategies implemented by teachers $(N=10)$

\begin{tabular}{llll} 
Teacher/Activity & WG & WP & WC \\
\hline TA & $Y$ & $Y$ & $Y$ \\
\hline TB & $Y$ & $N$ & $Y$ \\
\hline TC & $Y$ & $Y$ & $N$ \\
\hline TD & $Y$ & $Y$ & $Y$ \\
\hline TE & $Y$ & N \\
\hline TF & $Y$ & $Y$ & $Y$ \\
\hline TG & N & $Y$ & $Y$ \\
\hline TH & $Y$ & $Y$ & $N$ \\
\hline & $Y$ & $Y$ & \\
\hline
\end{tabular}




\begin{tabular}{llll}
\hline TI & $Y$ & $Y$ & $Y$ \\
\hline TJ & $Y$ & $N$ & $Y$ \\
\hline Total usage & 9 & 8 & 7
\end{tabular}

Note: $\mathrm{Y}=$ Yes, was employed; $\mathrm{N}=$ No, was not employed. WG = Working in groups; $\mathrm{WP}=$ working in pairs; $\mathrm{WC}=$ whole class teaching.

As Table 1 shows, the predominant teaching method employed by the teachers who were observed in their attempts to promote creativity in students' EFL writing was working in groups (WG).Working in pairs (WP) was the second while whole class (WC) teaching was the third. TE used the Work Group strategy as a means to use collaborative learning in class during an essay-writing lesson. He divided the writing work into different parts and assigned each part to different groups of students. After the class chose a topic, the class was divided into five groups, each group working on a different part of the essay (TE, Observation 2, May $17,2018)$.

TF used working in pairs and led the students' groups. He asked them to send an informal letter to their friends inviting them to come to Jordan. Following the students sharing and discussing ideas, TF asked the pairs to share their ideas through discussion to come up with new ideas. He then asked the students to list their ideas, phrases, and expressions, which they thought they could use in the writing tasks (TF, Observation 3 May 20, 2018). TJ was observed using whole-class teaching to help students write topics by questioning them and guiding them in the process (TJ, Observation 1, May 6, 2018).

\section{Discussion, Conclusion and Recommendations}

In this study, the participating teachers expressed their opinions on how they used collaborative learning strategy for promoting their students' creativity in EFL writing. For example, participating teacher TA claimed that his focus was on collaborative learning in which students displaying different levels of performance worked together in small groups to achieve a common goal. Classroom observations revealed that all the teachers who claimed to employ this strategy used a combined set of collaborative teaching activities like working in groups (WG), (e.g., TE) working in pairs (WP) (e.g., TF), and whole-class teaching (WC) (e.g., TJ). Collaborative learning encourages and promotes the maximum use of cooperative activities based on pair work and group work of learners in the classroom (Johnson, Johnson, \& Smith, 1991).

A theory of language as communication lies at the core of Collaborative Learning Theory. Hymes (1971) advanced the notions of "competence" and "performance" Chomsky introduced in the 1960s and stated that the goal of language teaching was to develop "communicative competence", which implied acquiring both ability and the knowledge to use language. In other words, communicative competence considers language to be tool used for communication. Not only does this competence focus on the development of four language skills, but also it depends on the correlation among the skills. Therefore, the communicative approach promoted the idea that social and cultural knowledge were necessary prerequisites for understanding and using linguistic forms. Vygotsky's socio-cultural theory posited that human learning couldn't be understood independently from the social and cultural forces that influence individuals and those sociocultural interactions are critical to learning.

McGroarty (1989) points to the benefits of collaborative learning, claiming that by using such learning students gain both in comprehension and production of the second/foreign language. A learning environment, with abundant activities promoting 
ideas exchange and interaction, contributes to learners' fluency and language mastery. CLT procedures require teachers to abandon teacher-centred classroom management skills. Students are expected to interact primarily with each other and then with the teacher (Brandl, 2007). Grouping students promotes CL, which has long been recognized as a strong facilitator of learning, and previous studies have found the impact of $\mathrm{CL}$ on students' creativity in writing. Rojas-Drummond et al. (2008), RojasDrummond et al. (2006) and, Hages (2008) studied the impact collaborative learning environment upon the writing abilities.

Additional research should be conducted and results should be interpreted and spread in the field for effective professional development. Teachers need information to support their classroom practice while EFL students require effective writing instruction that deviates from the traditional way of teaching.

\section{References}

Almwajeh, M., \& Rababah, L. (2019). There is more to it than meets the eye: an intercultural study of religious speech acts between Jordanian and American students. International Journal of Linguistics, 11 (1), 34-45.

Al-Nouh, N. A., Taqi, H. A., \& Abdul-Kareem, M. M. (2014). EFL Primary School Teachers' Attitudes, Knowledge and Skills in Alternative Assessment. International Education Studies, 7(5), 68-84.

AL Rababah, I., \& Rababah, L. (2019). The Use of Brainstorming Strategy Among Teachers of Arabic for Speakers of Other Languages (ASOL) in Writing Classes. International Journal of English Linguistics, 9 (1), 15-24. https://doi.org/10.5539/ijel.v9n1p15Auerbach, E. R., \& Wallerstein, N. (1987). English for the Workplace: ESL for Action: Problem Posing at Work. Addison-Wesley.

BaniKhlaf, A., \& Rababah, L. (2018). Gender differences and emotional expressiveness on Facebook: An analysis of prosodic features among Jordanian facebookers. Studies in Linguistics and Literature, 2 (3), 180-194. https://doi.org/10.22158/sll.v2n3p18

Biria, R., \& Jafari, S. (2013). The impact of collaborative writing on the writing fluency of Iranian EFL learners. Journal of Language Teaching and Research, 4(1), 164-175.

Brandl, K. (2007). Communicative Language Teaching in Action: Putting Principles to Work. Prentice Hall: Pearson.

Buchberger, F. (2001). Active learning in powerful learning environments: Retrieved from http://www.palinz.ac.at/team/homepage/BuchbergerF/01\%20FB\%20Activec.pdf.

Bygate, M., Swain, M., \& Skehan, P. (2013). Researching Pedagogic Tasks: Second Language Learning, Teaching, and Testing. London: Routledge.

Díaz-Rico, L.T. (2008). Strategies for Teaching English Learners. Boston: Allyn \& Bacon.

Dornyei, Z., \& Kubanyiova, M. (2014). Motivating Learners, Motivating Teachers: Building Vision in the Language Classroom. Cambridge: Cambridge University Press.

Dornyei, Z., \& Skehan, P. (2008). Individual differences in second language learning. British Journal of Educational Psychology, 70, 519-539.

Ekholm, P., Granlund, K., Kauppila, P., Mitikka, S., Niemi, J., Rankinen, K., Rasanen, J. (2007). Influence of EU policy on agricultural nutrient losses and the state of receiving surface waters in Finland. Agricultural and Food Science, 16(4), 282-300. 
Gerjets, P., Scheiter, K., Opfermann, M., Hesse, F. W., \& Eysink, T. H. (2009). Learning with hypermedia: The influence of representational formats and different levels of learner control on performance and learning behavior. Computers in human behavior, 25(2), 360-370.

Hayes, J. R. (2006). New directions in writing theory. In C.A. MacArthur, S. Graham, \& J. Fitzgerald (Eds), Handbook of writing research ( $2^{\text {nd }}$ ed.) (28-40). New York: Guilford Press.

Hayes, T., \& Ge, X. (2008, June). The effects of computer-supported collaborative learning on students' writing performance. In Proceedings of the 8th International Conference for the Learning Sciences -Volume 1, 335-341. Utrecht, the Netherlands: International Society of the Learning Sciences.

Hymes, D. H. (1971). Pidginization and creolization of languages. Proceedings of a Conference held at the University of the West Indies Mona, Jamaica, 121-125.

Johnson, D. W., Johnson, R. T., \& Smith, K. A. (1991). Active Learning: Cooperation in the College Classroom. Edina, MN: Interaction Book Company.

Krashen, S. (1982). Principles and Practice in Second Language Acquisition. Oxford: Pergamon.

Long, M.H., \& Crookes, G. (1992). Three approaches to task-based syllabus design. TESOL Quarterly, 26(1), 27-56.

McGroarty, M. (1989). The benefits of cooperative learning arrangements in second language instruction. NABE, 13(2), 127-143.

Parrish, B. (2004). Teaching Adult ESL: A Practical Introduction. New York: McGraw-Hill.

Rababah, L., \& Banikalef, (2019). The use of valuing strategies into enhancing creativity in EFL writing. Education and Linguistics Research, 5 (1), 30-36.

Rababah, L. (2018). An adapted version of Torrance test of creative thinking (TTCT) in EFL/ESL writing: A rubric scoring and a review of studies. International Journal of English and Education, 7(2), 128-136.

Rababah, L., \& Almwajeh, M. (2018). Promoting creativity in EFL/ESL writing through scaffolding strategy. International Journal of English and Education, 7(3), 148-160.

Rodgers, T. S. (2001). Language teaching methodology. ERIC Issue Paper. Retrieved from https://files.eric.ed.gov/fulltext/ED459628.pdf

Rojas-Drummond, S., Albarrán, C., \& Littleton, K. (2008). Collaboration, creativity and the co-construction of oral and written texts. Thinking Skills and Creativity, 3(3), 177-191.

Rojas-Drummond, S., Mazón, N., Fernández, M., \& Wegerif, R. (2006). Explicit reasoning, creativity and co-construction in primary school children's collaborative activities. Thinking Skills and Creativity, 1(2), 84-94.

William, W. (2009). Research Methods in Education. Noida, India: Pearson Education.

Willis, D., \& Willis, J. (2008). Doing Task-Based Teaching. Oxford: Oxford University Press. 